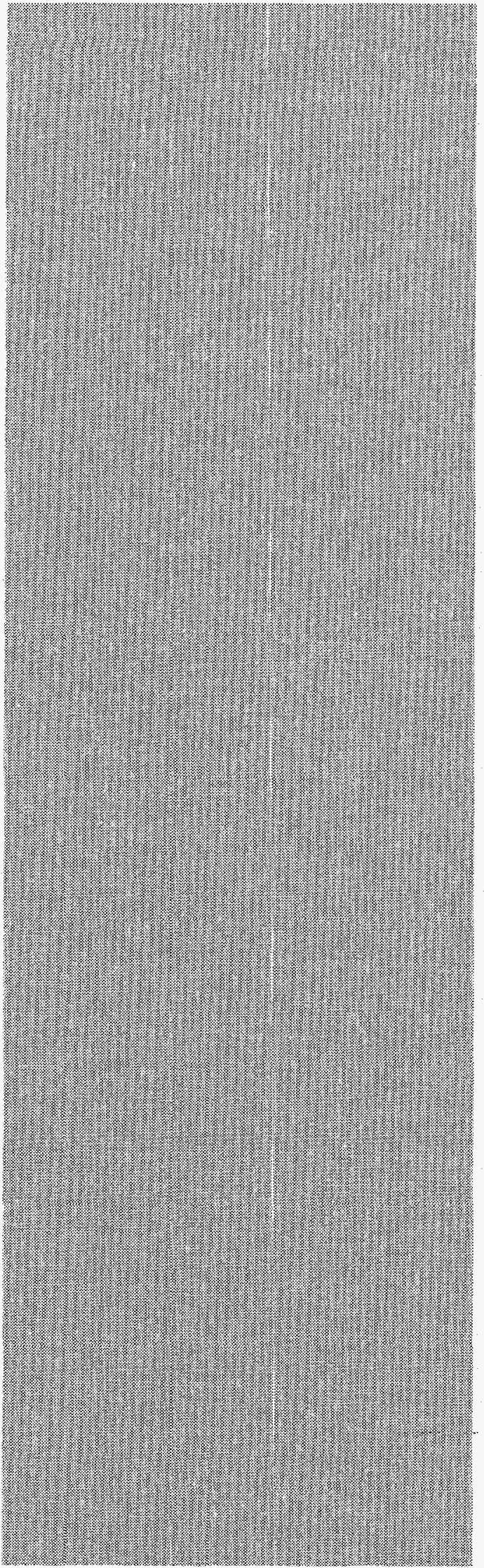

Polycyclic Aromatic Hydrocarbons at

Selected Burning Grounds at

Los Alamos National Laboratory

\section{Los Alamos \\ NATIONAL LABORATORY}

Los Alamos National Laboratory is operated by the University of California for the United States Department of Energy under contract W-7405-ENG-36. 
Edited by Cynthia Phillips, Group CIC-1

An Affirmative Action/Equal Opportunity Employer

This report was prepared as an account of work sponsored by an agency of the United States Government. Neither The Regents of the University of Califormia, the United States

Government nor any agency thereof, nor any of their employees, makes any warranty, express or implied, or assumes any legal liability or responsibility for the accuracy, completeness, or usefulness of any information, apparatus, product, or process disclosed, or represents that its use would not infringe privately owned rights. Reference herein to any specific commercial product, process, or service by trade name, trademark, manufacturer, or otherwise, does not necessarily constitute or imply its endorsement, recommendation, or favoring by The Regents of the University of California, the United States Government, or any agency thereof. The views and opinions of authors expressed herein do not necessarily state or reflect those of The Regents of the University of California, the United States Government, or any agency thereof. Los Alamos National Laboratory strongly supports academic freedom and a researcher's right to publish; as an institution, however, the Laboratory does not endorse the viewpoint of a publication or guarantee its technical correctness. 
Polycyclic Aromatic Hydrocarbons at Selected Burning Grounds at

Los Alamos National Laboratory

Betty W. Harris

Le Keisha M. Minor

Brandon J. Flucas 


\section{DISCLAIMER}

Portions of this document may be illegible electronic image products. Images are produced from the best available original document. 


\section{CONTENTS}

Abstract

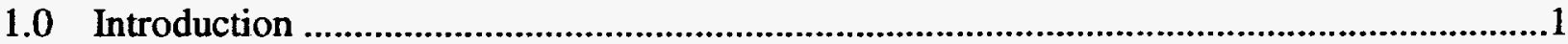

1.1 Historical Perspective of the Carcinogenesis of PAHs................................................

1.2 Stability of PAHs in the Soil..................................................................................5

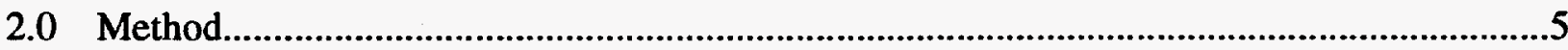

$2.1 \quad$ General Procedure for Burning.................................................................................6

2.2 Los Alamos National Laboratory Areas Sampled, Sample Collection, and Storage...6

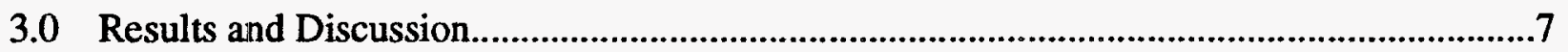

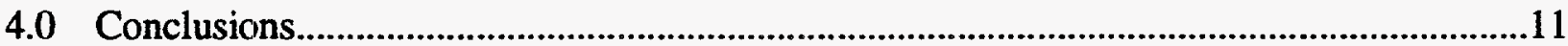

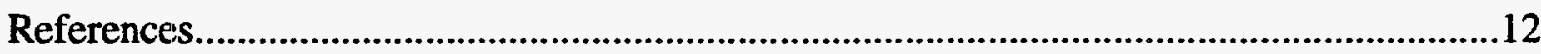

FIGURES

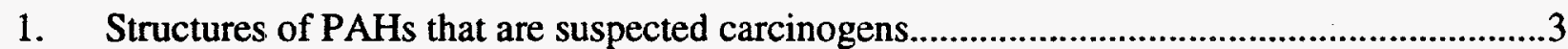

2. High-performance liquid chromatography (HPLC) spectrum of PAHs listed in EPA Method 8310.....................................................................................................

3. Locations of areas sampled for polycyclic aromatic hydrocarbons at the Los Alamos National Laboratory.

\section{TABLES}

I. High and low half-life data of PAHs in the soil based upon aerobic soil die-away studies at 283.15 to $303.15 \mathrm{~K}\left(10\right.$ to $\left.30^{\circ} \mathrm{C}\right)$.

II. Results of total PAHs in standard soil samples analyzed with the immunoassay field test kit. Accuracy range from 0.7 to $140 \mathrm{ppm}$.

III. Exposure limits for possible PAHs at Los Alamos National Laboratory

IV. Approximate temperatures used to burn debris from shots fired and to burn waste explosives at Los Alamos National Laboratory

V. Screening action limits (SAL) and concentrations (ppm) of PAHs in soil from a motor pool area as determined by LANL

VI. Total PAH concentrations found in burn areas soil samples.........................................16

VII. Concentration in ppm of total PAH in crude oil reference sample 16

\section{GLOSSARY}

DOE Department of Energy

EPA Environmental Protection Agency

IFT Immunoassay Field Test

OSHA Occupational Safety and Health Administration

PAH Polycyclic Aromatic Hydrocarbon 


\title{
Polycyclic Aromatic Hydrocarbons at Selected Burning Grounds at Los Alamos National Laboratory
}

\author{
Betty W. Harris," Le Keisha M. Minor, and Brandon J. Flucas
}

\begin{abstract}
A commercial immunoassay field test (IFT) was used to rapidly assess the total concentrations of polycyclic aromatic hydrocarbons (PAHs) in the soil at selected burning grounds within the explosives corridor at Los Alamos National Laboratory (LANL). Results were compared with analyses obtained from LANL Analytical Laboratory and from a commercial laboratory. Both used the Environmental Protection Agency's (EPA's) Methods 8270 and 8310. EPA's Method 8270 employs gas chromatography and mass spectral analyses, whereas EPA's Method 8310 uses an ultraviolet detector in a high-performance liquid chromatography procedure. One crude oil sample and one diesel fuel sample, analyzed by EPA Method 8270, were included for references. On an average the IFT results were lower for standard samples and lower than the analytical laboratory results for the unknown samples.

Sites were selected to determine whether the PAHs came from the material burned or the fuel used to ignite the burn, or whether they are produced by a hightemperature chemical reaction during the burn. Even though the crude oil and diesel fuel samples did contain measurable quantities of PAHs, there were no significant concentrations of PAHs detected in the ashes and soil at the burning grounds. Tests were made on fresh soil and ashes collected after a large burn and on aged soil and ashes known to have been at the site more than three years. Also analyzed were twelve-year-old samples from an inactive open burn cage.
\end{abstract}

\subsection{Introduction}

A major effort is being made by the US Department of Energy (DOE) to remediate facilities and grounds that are no longer needed but have been contaminated from past research, development, and testing of explosives and other weapon components. Excess real property cannot be released by DOE to the Department of Interior or to other agencies, whether federal, state, or local, until the proper assessment and cleanup are completed. Standards for remediation are established by the US Environmental Protection Agency (EPA), the Occupational Safety and Health Administration (OSHA) and the corresponding local and state entities. These regulations ensure that no hazardous materials remain in the environment that would cause immediate or long-term harm to the public during future use. This research is a part of this joint effort.

Today's epidemiologists believe that 70 to $90 \%$ of human cancer is caused by chemicals in the environment. ${ }^{1}$ PAHs are among the hazardous chemicals that persist in the soil and can have a detrimental effect on human health. They are regulated by OSHA. A rapid detection method for

- Principal investigator 
them in the soil could be a cost-saving and very important screening tool to produce invaluable data needed in making decisions associated with the environmental remediation process. The immunoassay field test (IFT) shows promise of being this tool.

The IFT has been used extensively in the drug industry for many years; it is the method most often used and contested in adversarial matters involving substance-abuse testing.

\subsection{Historical Perspective of the Carcinogenesis of PAHs}

PAHs are carbon-rich, hydrogen-deficient, fused-ring aromatic hydrocarbons that range in structure from the simple two-ring system of naphthalene to the more complex graphite or diamond elemental arrangement. They are reputedly produced biochemically in nature, but they are historically obtained from coal tar or from the incomplete combustion or pyrolysis of organic materials. Common sources of PAHs are heavy petroleum products such as fuel oil and crude oils, creosote used in wood preservation, particulates in diesel fuel and other engine exhaust, barbecued or charbroiled food, wood-burning stoves, cigarette smoke, forest fires, and volcanoes. ${ }^{2}$ Much of the interest in complex nuclear hydrocarbons has arisen because a considerable number of them have cancer-producing properties.

In the late eighteenth century, Percival Pott, a British physician, correctly attributed the high incidence of scrotal cancer among chimney sweeps of London to their continual contact with coal tar and their poor hygienic living conditions. ${ }^{3}$ The first experimental evidence for chemical carcinogenics was obtained in 1915 by Yamagiwa and Ichikawa when they repeatedly applied coal tar to the ears of rabbits. The rabbits developed malignant tumors. ${ }^{4}$ One of the most studied carcinogens, benzo(a)pyrene was isolated from coal tar by Cook, Kennaway, and collaborators in the mid-1930s. ${ }^{5}$ Since that time numerous other cancer-causing chemicals have been found. It was estimated in the 1970 s that 2,000 tons of benzo(a)pyrene were released into the air over the United States each year. ${ }^{6}$ Imposed regulations have not reduced this amount significantly.

Some of the most powerful potential carcinogens are benzo(a)pyrene and the derivatives of 1,2benz(a)anthracene. Structures for 1,2 benz(a)anthracene and other PAHs of interest are given in Figure 1. EPA's Method 8310, which uses high-performance liquid chromatography (HPLC), is generally used to quantify PAHs in environmental samples (see diagram in Figure 2). 
<smiles>c1cc2c3c(cccc3c1)CC2</smiles>

Acenaphthene<smiles>c1ccc2cc3c(ccc4ccccc43)cc2c1</smiles>

Benz(a)anthracene<smiles></smiles>

Benzo(g, $h$, i)perylene<smiles>c1ccc2c(c1)ccc1c3ccccc3ccc21</smiles>

Chrysene<smiles>c1ccc2c(c1)Cc1ccccc1-2</smiles>

Fluorene<smiles>c1ccc2c(c1)ccc1ccccc12</smiles>

Phenanthrene<smiles></smiles>

Acenaphthylene<smiles></smiles>

Benzo(b)fluoranthene

Benzo(k)fluoranthene<smiles>c1ccc2c(c1)cc1ccc3cccc4ccc2c1c34</smiles>

Benzo(a)pyrene<smiles>c1ccc2c(c1)ccc1cc3c(ccc4ccccc43)cc12</smiles>

Dibenzo(a,h)anthracene

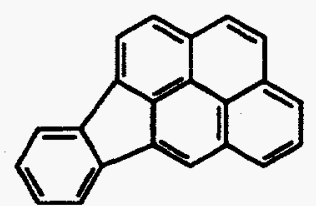

Indeno(1,2,3-c, d)pyrene<smiles>c1cc2ccc3cccc4ccc(c1)c2c34</smiles>

Pyrene<smiles></smiles>

Benzo(e)pyrene

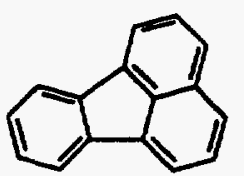

Fluoranthene<smiles>c1ccc2ccccc2c1</smiles>

Naphthalene

Figure 1. Structures of PAHs that are suspected carcinogens. 
Columin: HC-ODS SIL-X

Mobile Phase: $40 \%$ to $100 \%$ Acetonitrile in Water

Detector: Fluorescence

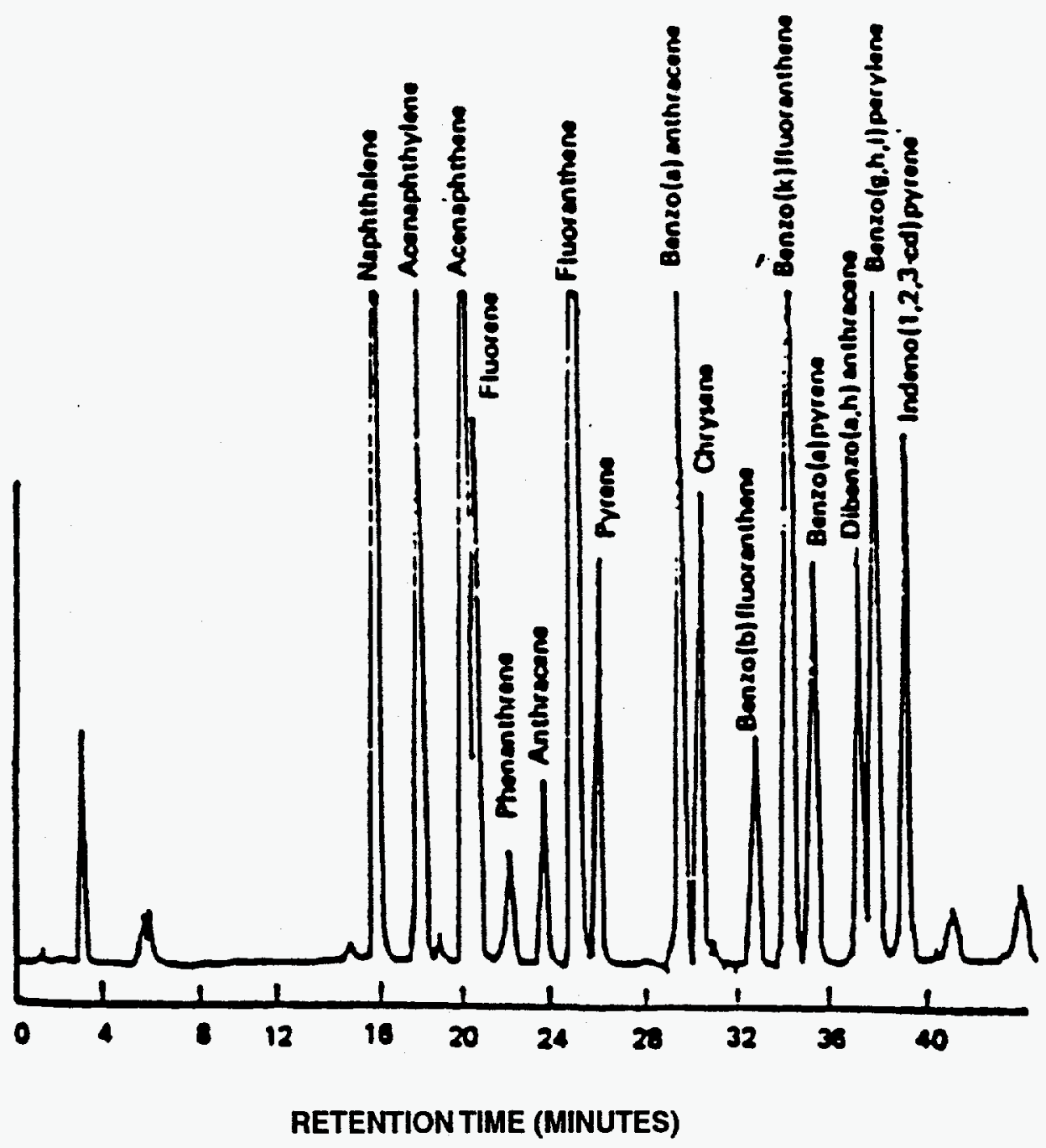

Figure 2. High-performance liquid chromatography (HPLC) spectrum of PAHs listed in EPA Method 8310. 
More recent studies, done in 1983 by the International Agency Research on Cancer working group, confirm the concern for the carcinogenesis of PAHs. Benzo(a)pyrene, benz(a)anthracene, chrysene, benzofluoroanthenes, and indenopyrene were identified as having moderate to high levels of evidence for causing cancer in animals. ${ }^{7}$ These 5 PAHs were among 41 studied by the group. It may be inferred from the data from the studies that these are the compounds in air and food that are most likely to cause cancer in humans.

\subsection{Stability of PAHs in the Soil}

The chemical and biological stability of PAHs is significant to our study because of sample quality assurance and degradation products. Their chemical stability is accredited to their aromaticity, a conjugated pi electron system above and below the plane of the orbital. PAHs are solids at room temperature, with the exception of a few hydrogenated ones, and they are the least volatile of the hydrocarbons. The boiling points of PAHs are much higher than those of straightchained counterparts with the same number of carbons. But losses from environmental samples can be great, as much as $88 \%$ for pyrene and $32 \%$ from particulates stored in the dark in open containers. ${ }^{8}$ Limited half-life data for PAHs in the soil are found in Table I. ${ }^{9-12}$

\subsection{Method}

The immunoassay is a diagnostic test that uses antibodies to bind (detect) specific antigens (analytes) without reacting to nontargeted compounds. Technician training is minimal, and the test is readily adapted to the field environment. However, the test must be performed properly and the IFT kit must be stored at 5 to $20^{\circ} \mathrm{C}$ in order to get the best results. The field work station has sufficient storage capacity for 3 test packs of components, which allows the user to analyze up to 30 samples, including standards. The IFT used in this study was developed strictly for the assessment of total PAHs in the soil. Antibody/antigen relationships have been established for diphenylamine, nitrotoluenes, and the following PAHs:

acenaphthene
acenaphthalene
alkylnaphthalenes
anthracene
anthraquinone
benz(a)anthracene
benzo(b)fluoranthene
benzo(k)fluoranthene
benzo(g,h,i)perylene
benzo(a)pyrene
chloronaphthalene
chrysene
dibenz(a,h)anthracene
fluoranthene
fluorene

acenaphthene acenaphthalene alkylnaphthalenes anthracene anthraquinone benz(a)anthracene benzo(b)fluoranthene benzo(g,h,i)perylene benzo(a)pyrene chloronaphthalene chrysene fluoranthene fluorene 
Ultraviolet spectroscopy is used successfully in the analysis of PAHs. The $\pi$-to- $\pi$ orbital transition caused by the absorption of radiation in the low-energy pi-antibonding orbitals to the high-energy bonding orbitals makes this technology possible.

\subsection{General Procedure for Burning}

Prior to 1982, nearly all of the burns at LANL occurred on the open ground. Materials were spread out on the surface, surrounded with combustible materials, drenched with fuel, and ignited. Now some areas have waste explosives, or waste material contaminated with explosives, burned in an open tray with an ash collection tray beneath. The partially enclosed method (top removed) may limit the amount of oxygen in the burn, thereby causing a hydrocarbon-rich flame, and in theory, may increase the possibility of PAHs being formed. The temperature of the burn is very important because it ensures the complete destruction of the waste. Some suggest that it may determine whether or not PAHs are produced in the burning process.

\subsection{LANL Areas Sampled, Sample Collection, and Storage}

A stainless steel scoop was used to mix and remove soil from the first six inches of earth and to remove ash from the burn trays and barrels. The composite samples were placed in glass bottles sealed with Teflon-lined caps and tested immediately using the IFT kit. Samples were also collected for fixed-laboratory analyses. These samples were transported in an insulated, cooled ice chest and then were kept under refrigeration during the holding time, which did not exceed 48 hours. Sets of standard samples from commercial laboratory and prepared standards were stored under refrigeration until used; Table II shows average results, in parts per million (ppm), of 30 standard-soil samples prepared and tested with the IFT kit for total concentrations of PAHs. The accuracy of the kit reported by the factory ranges from 0.7 to $140 \mathrm{ppm}$. Permissible exposure limits (PELs) for Category 1 chemicals (known and suspected OSHA carcinogens, reproductive toxins, and acutely toxic substances) were used to select soil samples for further testing. Table III provides a list of PAHs included in LANL's Administrative Requirement 6.3 Category 1 chemicals. 
Figure 3 shows the locations at LANL that were sampled for PAHs. Descriptions of the buming grounds sampled for this study at various technical areas (TAs) at LANL follow:

\begin{tabular}{|l|l|}
\hline \multicolumn{1}{|c|}{ Location } & \multicolumn{1}{c|}{ Descriptions of Burning Grounds } \\
\hline $\begin{array}{l}\text { TA-14, Q-Site open-burn } \\
\text { box }\end{array}$ & $\begin{array}{l}\text { A steel barrel about } 3 \mathrm{ft} \text { high and } 2 \mathrm{ft} \text { in diameter is used to burn } \\
\text { explosives-contaminated waste. The waste is placed in the box, } \\
\text { covered with kerosene, and burned. Samples were taken from the } \\
\text { box and the soil beneath the box. }\end{array}$ \\
\hline $\begin{array}{l}\text { TA-16-399, S-Site active } \\
\text { burn tray }\end{array}$ & $\begin{array}{l}\text { A steel-covered rectangular tray that rests on a wheel-and-track } \\
\text { apparatus is used to burn pure and formulated waste explosives, } \\
\text { characterized combustible materials contaminated with explosives, } \\
\text { wires, detonators, and solvents. Samples were taken from the ash in } \\
\text { the tray and from the soil beneath the tray. }\end{array}$ \\
\hline $\begin{array}{l}\text { TA-36, Lower Slobbovia } \\
\text { active open-burn area }\end{array}$ & $\begin{array}{l}\text { No explosives are burned at this site. The waste is mostly untreated } \\
\text { wood and debris from shots. The wood may have metal plates, nails, } \\
\text { or banding metal attached. To ignite the burn, paper or Kimwipes } \\
\text { are placed on the waste, the surface is soaked with not more than } 10 \\
\text { gallons of kerosene, and the materials are ignited with a weed } \\
\text { blower or a match. The temperatures of the burms are given in Table } \\
\text { IV. Soil samples were taken immediately after each burn. }\end{array}$ \\
\hline $\begin{array}{l}\text { TA-40 Detonator Facility } \\
\text { Firing Site, inactive } \\
\text { open-bum cage }\end{array}$ & $\begin{array}{l}\text { A cylindrical steel cage about } 12 \text { ft high by } 6 \text { ft in diameter with a } \\
\text { tray beneath to collect the ashes is used to burn debris from } \\
\text { detonator tests. Samples were taken from the tray and the soil } \\
\text { beneath the tray. }\end{array}$ \\
\hline
\end{tabular}

Soil from a waste storage area and a motor pool area were assessed for PAHs. A gas station, a diesel pad, and a tank farm were analyzed. Results are in Table V.

\subsection{Results and Discussion}

The human population is being exposed to carcinogens at an increasing rate as a consequence of industrial growth. Although the molecular basis for the mechanism of action of PAH carcinogens is unknown, the initial biological receptor for the hydrocarbon has been identified as the microsomal mixed-function oxidases. ${ }^{13}$ Aryl hydrocarbon hydroxylase is such an enzyme; it has been extensively studied in rodent systems and has been found in human liver, skin, placenta, lymphocytes, and monocytes. This enzyme converts PAHs to various hydroxylated derivatives, including phenols, dihydrodiols, quinones, and epoxides. Some of the epoxides are more carcinogenic in vitro than is the parent hydrocarbon. Thus the enzyme complex likely functions in both activation and detoxification. Exposure to cigarette smoke, pesticides, and PAHs induces the enzyme's activity and may alter human susceptibility to PAH carcinogenesis. This concern is the driving force for examining the PAHs at LANL burning grounds. 


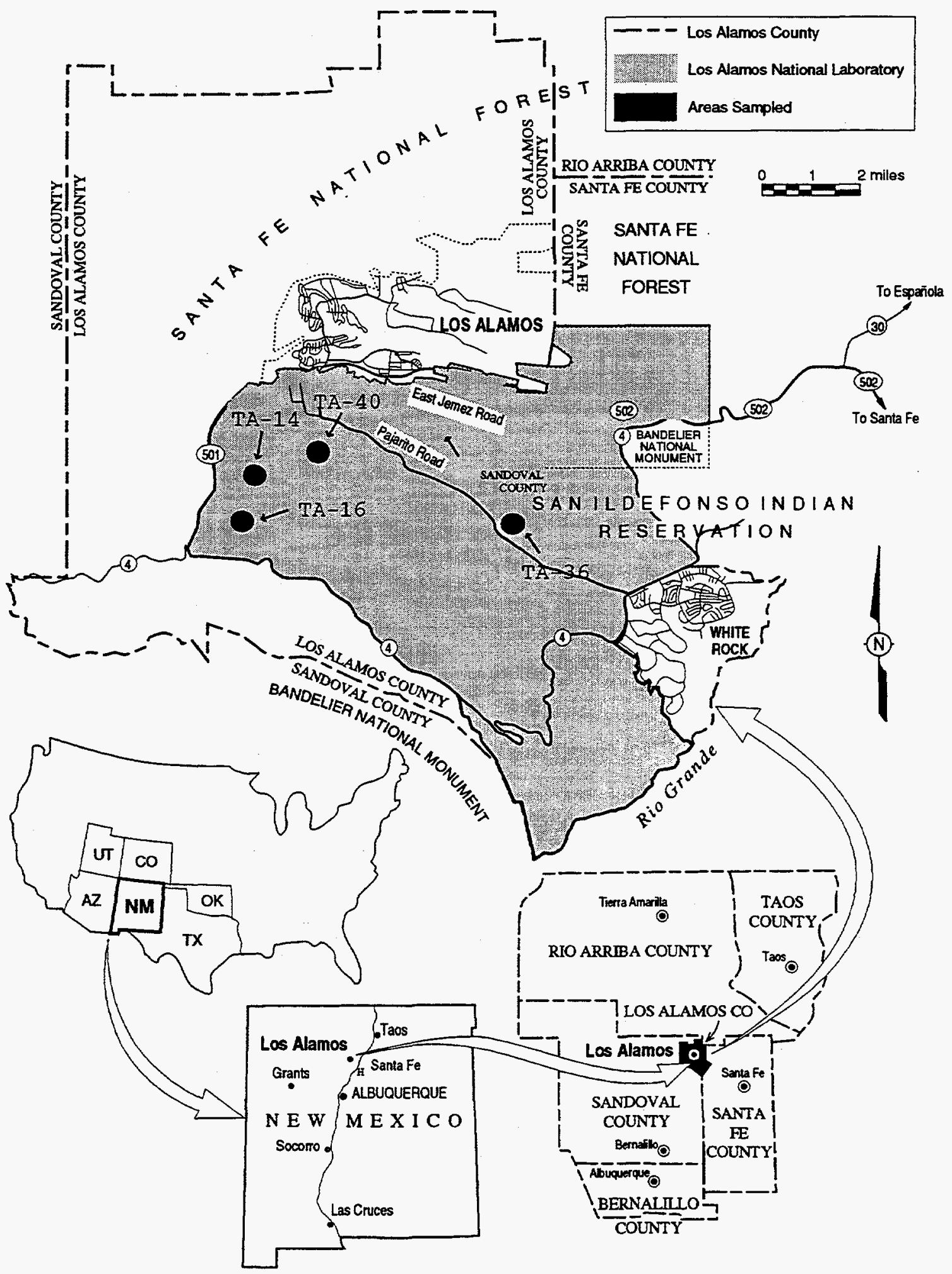

Figure 3. Locations of areas sampled for polycyclic aromatic hydrocarbons at the Los Alamos National Laboratory. 
Many questions arise in the discussion of the health hazards associated with dust and soil at open-burning disposal areas in the explosives corridor. Are the concentrations of PAHs sufficient to pose a problem to human health? Are PAHs produced during the burn or do they come from the fuel added? What compounds persist in the soil over long periods of time? With the aid of the IFT, this study answered some of these questions.

Results from IFT, the commercial laboratory, and LANL analytical laboratory in parts per million (ppm) of total PAHs, in the soil, are shown in Table VI. Most of the samples analyzed by the commercial laboratory using EPA Method 8310 did not show a detectable amount of PAHs, while LANL and IFT found less than $20 \mathrm{ppm}$ of total PAHs. These results were low when compared to the standards. These total concentrations of PAHs in the soil do not pose a threat to humans working at the burning grounds within the explosive corridor. Table VII shows the results from the crude oil reference sample. The IFT indicated the crude oil sample had a measurable concentration of PAHs, but PAHs were not detected by the commercial laboratory, who used a lower cut-off limit (1000 ppm) that was higher than the upper limit of PAHs in the sample. LANL analyses of the crude oil reference sample were more in agreement with those expected, as compared with Strata Production Company's analyses. LANL found $250 \mathrm{ppm}$ naphthalene, $300 \mathrm{ppm} 2$-methyl-naphthalene, $24 \mathrm{ppm}$ fluorene, and $61 \mathrm{ppm}$ anthracene for a total PAH concentration of $635 \mathrm{ppm}$ in the crude oil. Strata Production, who provided the sample, showed $710 \mathrm{ppm}$ of total PAHs.

Preliminary assessment samples in other areas showed levels of PAHs that exceeded the screening action levels (SALs) established. A closer investigation revealed that most of these were in motor pool or disposal areas where the chemicals could concentrate over a long period of time (see Table V). The diesel pad was the most contaminated of all the petroleum areas that were preassessed. Compounds exceeding the SALs and the PEL for OSHA Category 1 chemicals (from Table III) were as follows:

benz(a)anthracene,
benzo(a)pyrene,
benzo(b)fluoranthene,
benzo(g,h,i)perylene,
benzo(k)fluoranthene,
chrysene, and
indeno( $1,2,3-\mathrm{c}, \mathrm{d})$ pyrene.

Therefore, we conclude that prolonged exposure to petroleum-contaminated soil at Los Alamos can cause health problems for humans because of the concentrations of PAHs in the soil. 
Burn areas in the explosives corridor use kerosene or other fuels to initiate the burn, but the fuel is not allowed to become concentrated in the soil. Other than the materials and substances burned, this is the only possible source of PAHs. The half-lives of the PAHs of concern range from one to five years as indicated in Table I. Most of PAHs would biodegrade within a fiveyear period of time.

Thermal decomposition of the PAHs would occur during the burning of the explosives and other waste; see Table IV for the temperatures used to burn various materials.

Soot from hydrocarbon-rich flames is known to contain many hydrocarbons, including benzo(a)pyrene. How the PAH is formed and whether or not it is merely absorbed on the surface of the soot has not been clearly delineated. ${ }^{1416}$ Chakraborty and Long used an ethylene diffusion flame in which mixtures of oxygen-nitrogen and oxygen-argon were supplied to the burn. They studied the effects of changing the oxygen index (i.e., the mole fraction of oxygen in the mixture) on the production of PAHs. Dry soot was extracted with chloroform to recover the PAHs and carbonaceous residue produced. In the oxygen-nitrogen mixtures there was a rapid decline in the amount of PAHs in soot as the oxygen index increased from 0.18 to 0.26 . The amount of soot reached a maximum when the oxygen index was 0.26 and above this value it declined rapidly being then composed almost entirely of carbonaceous materials. Substitution of nitrogen for argon lead to higher temperatures in the reaction and pyrolysis zones. At lower oxygen indices the formation of carbonaceous residue is favored. At higher oxygen indices the amount of soot (carbonaceous residue) is less. Either a general or local depletion of oxygen could produce more PAHs. This justifies our concern for burns at LANL in which a partial cover is used over the burn. N. Zaghini et al. have measured the main reaction products (hydrocarbons and PAHs) along a vertical flow reactor on which cool, blue and yellow flames of an $n$-heptane/ oxygen/nitrogen mixture were stabilized at atmospheric pressure. Several hydrocarbonsvinylacetylene, benzene, toluene, xylenes, styrene, ethynylbenzene and methylnaphthalenewere found in the blue and yellow flame by means of GC-MS. Hydrocarbons, they believe are intermediates in the formation of PAHs. Tompkins' study of premixed oxy-acetylene flames revealed PAHs may also be coming from the pyrolysis of residual acetylene. The temperature range in his study is 650 to $900^{\circ} \mathrm{C}$; temperatures that are common in the burning of waste explosives and shot debris at LANL, which may get as high as $1100^{\circ} \mathrm{C} .{ }^{17}$ It has been shown that the blue reaction zone of the flame results in dehydrogenation and decomposition of residual hydrocarbon species that provide acetylene radicals. Polyacetylenes are then formed that further dehydrogenate to $C_{2}$ to $C_{6}$ hydrocarbon radical, precursor to PAHs. 


\subsection{Conclusions}

Sites were selected to determine whether the PAHs came from the material burned, the fuel used to ignite the burn, or whether they were produced by a high-temperature chemical reaction during the burn. Even though the crude oil and diesel fuel samples did contain measurable quantities of PAHs, there were no significant concentrations of PAHs detected in the ashes and soil at the burning grounds, where fuel (kerosene) was poured on the debris or explosives and ignited. Tests were made on fresh soil and ashes collected after a large burn and on aged soil and ashes known to have been at the site more than three years. Also analyzed were twelve-year-old samples from an inactive open burn cage. None of these showed significant amounts of PAHs.

The IFT and the prepared soil standards indicated that the immunoassay-based test method is accurate enough to be used effectively in adverse weather conditions (extreme cold and heat) and field conditions (hard-to-access environmental locations such as canyons and mountain tops). For LANL, the immunoassay kit would be ideal for the assessment of contaminated areas after cleanup. Other conclusions concerning the use of the IFT include the following:

- The kit is well packaged and easy to use in the field.

- The kit shows promise as an effective screening and cleanup tool.

- At high concentrations of PAHs ( $>500 \mathrm{mmol} / \mathrm{kg}$ ) the kit will give results that are much lower than the actual total concentrations of PAH in the soil.

- The absence of PAHs in ash immediately following a burn of wood, paper, and other shot debris disproves the theory that PAHs are high-temperature reaction products from the debris burned.

- The concentration of the PAHs in the burning grounds located within the explosives corridor at LANL are below the level of concern for health risk. Motor pools and gas islands showed the highest degree of contamination of PAHs in the soil. The levels found can pose a risk to human health, if there is prolonged exposure.

- PAHs in the soil at the burning grounds within the explosives corridor come from the fuel used to ignite the burning rather than from waste materials that are burned. This conclusion is based on the temperature of the burn and the concentrations of contaminants reported in the ash immediately following the burn that was started by first dossing fuel on the material to be burned.

- The relatively short half-lives ( 1 to 5 years) of the PAHs also reduce the probability of concentration build-up in the soil. Because the IFT gave repeatedly low results it could not be 
used for quantity assessments. However, in the field the mere detection of PAHs in the soil using the IFT should be enough to warrant a thorough investigation.

\section{References}

1. J. Higginson and C. S. Muir, "Epidemiology" Cancer Medicine, J. F. Holland and E. Frei II, Eds. Lea and Febger, Philadelphia, Pennsylvania, pp 241-306 (1973).

2. J. K. Rosenfield and R. H. Plumb, "Ground Water Contamination at Wood Treatment Facilities," Ground Water Monitor Rev. inter: pp 133-140 (1991).

3. P. Pott, Chirurgical, p 63, Hawkes, Clarke, and Collins, London (1975).

4. K. Yamagiwa and K. Ichikawa, Experimentelle Studien uber die Pathogenese der Epithelialgeschwulste (II Mitteilung), Mitteil Med. Fakultat Kaiserl. Univ., Tokyo, Vol. 17 (I) p 19 (1917).

5. J. W. Cook, C. L. Hewett, and I. Hieger, "Isolation of Cancer-Producing Hydrocarbons from Coal Tar," I. "Concentration of the Active Substance," J. Chem Soc., pp 395-402 (1933).

6. Particulate Polycyclic Organic Matter, National Academy of Science, Washington, D. C. (1972).

7. P. G. N. Kramer and C. A. Van der Heijden, "Polycyclic Aromatic Hydrocarbons -(PAH): Carcinogenicity Data and Risk Extrapolations," Toxicological and Environmental Chemistry Vol. 16, pp 341-351 (1983).

8. M. L. Lee, M. V. Novotny, and K. D. Bartles, Analytical Chemistry of Polycyclic Aromatic Compounds, Academic Press, New York (1981).

9. M. P. Coover and R. C. Sims, "The Effects of Temperature on Polycyclic Aromatic Hydrocarbons Persistence in an Unacclimated Agricultural Soil," Hazardous Waste Materials, Vol. 4, pp 69-82 (1987).

10. R. C. Sims, "Fate of PAH Compounds in Soil:Loss Mechanisms," Environ. Tox. Chem. Vol. 9 (1990).

11. D. Groenewegen and H. Stolpe, "Microbial Breakdown of Polycyclic Aromatic Hydrocarbons," Zentralbl. Bakteriol.Parasitenskr. Hyg., Abt. 1:Orig. Reihe, B 162: pp 225232 (1976).

12. D. F. Kincannon and Y. S. Lin, "Microbial Degradation of Hazardous Wastes by Land Treatment," Proc. Ind. Waste Conf. Vol. 40, pp 607-619 (1985).

13. D. W. Nebert and H. V. Gilboin, "Substrate-inducible Microsomal Aryl Hydroxylases in Mammalian Cell Culture," J. Biol. Chem., Vol. 243, pp $6242-6249$ (1968).

14. B. B. Chkraborty and R. Long, Combustion and Flame, Vol. 12, p 226 (1968a).

15. E. E. Tompkins and R. Long, 12th International Symposium on Combustion, The Combustion Institute of Pittsburgh, PA, p 625 (1969).

16. N. Zighini, S. Mangolini, G. Cornetti, T. Salvatori, and G. Rizzi, Combustion Science Technology, Vol. 5, p 225 (1972).

17. K. H. Homann and H. Gg. Wagner, 11 International Symposium on Combustion, The Combustion Institute, Pittsburgh, PA, p 371 (1967). 
Table I. High and low half-life data of PAHs in the soil based upon aerobic soil die-away studies at 283.15 to $303.15 \mathrm{~K}\left(10\right.$ to $\left.30^{\circ} \mathrm{C}\right)$.

\begin{tabular}{|c|c|c|c|c|}
\hline \multirow[t]{2}{*}{ Chemical } & \multirow[t]{2}{*}{ CAS Number ${ }^{\circ}$} & \multicolumn{2}{|c|}{ Half-Lives $^{b}$} & \multirow[t]{2}{*}{ Ref. ${ }^{\circ}$} \\
\hline & & High & Low & \\
\hline Benz(a)pyrene & $50-32-8$ & $1.45 y$ & $57 \mathrm{~d}$ & 1,2 \\
\hline di-Benz $(a, h)$ anthracene & $53-70-3$ & $2.58 y$ & $361 \mathrm{~d}$ & 1 \\
\hline Benza(a)anthracene & $56-55-3$ & $1.86 \mathrm{y}$ & $102 d$ & 1,2 \\
\hline $\begin{array}{l}\text { 7,12-dimethylbenz- } \\
\text { anthracene }\end{array}$ & $57-97-6$ & $28 d$ & $20 d$ & 3 \\
\hline Phenanthrene & $85-01-8$ & $200 d$ & $16 d$ & 1,3 \\
\hline Naphthalene & $91-20-3$ & $48 d$ & $16.4 \mathrm{~d}$ & 4 \\
\hline Anthracene & $120-12-7$ & $1.26 \mathrm{y}$ & $50 d$ & 1,3 \\
\hline Pyrene & $129-00-0$ & $5.2 \mathrm{y}$ & $210 d$ & 1,3 \\
\hline 1,2,7,8 di-Benzopyrene & $189-55-9$ & $361 d$ & $232 d$ & 2 \\
\hline Benzo(g,h,i)perylene & $191-24-2$ & $650 d$ & $590 \mathrm{~d}$ & 1 \\
\hline Indeno(1,2,3-cd)pyrene & $193-39-5$ & $2.0 y$ & $1.64 \mathrm{y}$ & 1 \\
\hline Benzo(b)fluorathene & $205-99-2$ & $1.67 y$ & $360 d$ & 1 \\
\hline Fluorathene & $206-44-0$ & $440 \mathrm{~d}$ & $140 \mathrm{~d}$ & 1 \\
\hline Benzo(k)fluorathene & $207-08-9$ & $5.86 y$ & $2.49 y$ & 1 \\
\hline Chrysene & $218-01-9$ & $2.72 y$ & $1.02 y$ & 1 \\
\hline Benz(c)acridine & $225-51-4$ & $1.0 \mathrm{y}$ & $0.5 \mathrm{y}$ & 1,2 \\
\hline Acenaphthalene & $208-96-8$ & $60 \mathrm{~d}$ & $42.5 d$ & \\
\hline
\end{tabular}

' Chemical Abstract Service

${ }^{b} \mathrm{y}$, d (year, day)

c 1. M. P. Coover and R. C. Sims, "The Effects of Temperature on Polycyclic Aromatic Hydrocarbons Persistence in an Unacclimated Agricultural Soil," Hazardous Waste Materials, Vol. 4, pp 69-82 (1987).

2. R. C. Sims, "Fate of PAH Compounds in Soil:Loss Mechanisms," Environ. Tox. Chem., Vol. 9, (1990).

3. D. Groenewegen and H. Stolpe, "Microbial Breakdown of Polycyclic Aromatic Hydrocarbons," Zentralbl. Bakteriol. Parasitenskr. Hyg., Abt. 1:Orig. Reihe, B 162: 225-232 (1976).

4. D. F. Kinciannon and Y. S. Lin, "Microbial Degradation of Hazardous Wastes by Land Treatment," Proc. Ind. Waste Conf., Vol. 40, pp 607-619 (1985). 
Table II. Results of total PAHs in standard soil samples analyzed with the immunoassay field test (IFT) kit. Accuracy range from 0.7 to $140 \mathrm{ppm}$.

\begin{tabular}{|l|l|l|}
\hline \multicolumn{1}{|c|}{ Compounds } & Known Concentration (ppm) & $\begin{array}{l}\text { Concentration (ppm) Measured } \\
\text { Using IFT Kit }\end{array}$ \\
\hline Anthracene & 124 & 24.0 \\
\hline Acenaphthene & 124 & 101 \\
\hline Chrysene & 134 & 21.0 \\
\hline Naphthalene & 120 & 30 \\
\hline Phenanthrene & 124 & 158 \\
\hline Pyrene & 120 & 75 \\
\hline
\end{tabular}

Table III. Exposure limits for possible PAHs at Los Alamos National Laboratory.

\begin{tabular}{|c|c|c|c|c|}
\hline $\begin{array}{c}\text { Chemical Abstract Service } \\
\text { Number }\end{array}$ & $\begin{array}{c}\text { Carcinogen } \\
\text { Name }\end{array}$ & R/E & PELTLV (8h TVA) & Source Agency \\
\hline 2-Acetylamino-fluorene & $53-96-3$ & IS & [1910.1014] & $\mathrm{O}, \mathrm{N}-2$ \\
\hline Benzo(a)Pyrene & $50-38-8$ & & $0.2 \mathrm{mg} / \mathrm{m}^{3} \mathrm{PEL}$ & G-A2, I-A2,N-2 \\
\hline Benzo(b)fluor-anthene & $205-99-2$ & 1 & none & $\mathrm{G}-\mathrm{A} 2, \mathrm{I}-2 \mathrm{~B}, \mathrm{~N}-2$ \\
\hline Chloronaphazine & 494-03-1 & & none & $1-1$ \\
\hline Chrysene & 218-01-09 & 1 & $0.2 \mathrm{mg} / \mathrm{m}^{3} \mathrm{PEL}$ & G-A2 \\
\hline Chrysotile & $12001-29-5$ & 1 & $0.2 \mathrm{f} / \mathrm{cc}$ PEL & $\mathrm{O}, \mathrm{G}-\mathrm{A} 1, \mathrm{l}-1, \mathrm{~N}-1$ \\
\hline Coal Tar Pitch Volatiles & $65996-93-2$ & IS & $0.2 \mathrm{mg} / \mathrm{m}^{3} \mathrm{PEL}$ & $\mathrm{G}-\mathrm{A} 1, \mathrm{I}-1, \mathrm{~N}-1$ \\
\hline 2-Naphthylamine & $91-59-8$ & & [1910.1009] & $0, G-A 1,1-1, N-1$ \\
\hline Alpha-Naphthylamine & $134-32-7$ & & [1910.1004] & 0 \\
\hline $\begin{array}{l}\text { Particulate Polycyclic Aromatic } \\
\text { Hydrocarbons }\end{array}$ & $65996-93-2$ & IA & $0.2 \mathrm{~m} / \mathrm{m}^{3} \mathrm{PEL}$ & $\mathrm{G}-\mathrm{A} 1,1-1, \mathrm{~N}-1$ \\
\hline N-Phenyl-b-naphthylamine & $135-88-6$ & & none & G-A2 \\
\hline
\end{tabular}

$\mathrm{PEL}=$ permissible exposure limit

TLV=threshold limit value

$R / E=$ route of entry

TVA $=$ time valued average 
Table IV. Approximate temperatures used to burn debris from shots fired and to burn waste explosives at Los Alamos National Laboratory.

\begin{tabular}{|l|l|l|}
\hline \multicolumn{1}{|c|}{ Material Burned } & \multicolumn{1}{|c|}{ Burn Temperature ${ }^{\circ} \mathrm{F}$} & \multicolumn{1}{c|}{ Burn Temperature ${ }^{\circ} \mathrm{C}$} \\
\hline Wood & 990 to 930 & 486 to 503 \\
\hline Paper & 842 to 1112 & 450 to 600 \\
\hline HMX & 2000 to 2100 & 1102 to 1158 \\
\hline Cast High Explosives & 1800 to 1850 & 990 to 1018 \\
\hline TATB & 842 to 1112 & 542 to 570 \\
\hline
\end{tabular}

Table V. Screening action limits (SAL) and concentrations (ppm) of PAHs in soil from a motor pool area as determined by LANL.

\begin{tabular}{|c|c|c|c|c|c|}
\hline Compound & SAL & $\begin{array}{c}\text { Gas } \\
\text { Station }\end{array}$ & $\begin{array}{c}\text { Diesel Fuel } \\
\text { Pad }\end{array}$ & Tank Farm & $\begin{array}{c}\text { Waste } \\
\text { Storage Area }\end{array}$ \\
\hline Acenaphthene & 4,800 & $\mathrm{ND}^{*}$ & 34.7-35.9 & ND & ND \\
\hline Acenaphthylene & -...- & ND & 1.5 & ND & ND \\
\hline Anthracene & 24,000 & ND & 54.1-59 & ND & ND \\
\hline $\begin{array}{l}\text { Benz(a)- } \\
\text { anthracene }\end{array}$ & 0.64 & ND & $65.3-66.7$ & 0.82 & 0.48 \\
\hline Benzo(a)pyrene & 0.1 & 0.39 & $0.43-53.8$ & 0.85 & ND \\
\hline $\begin{array}{l}\text { Benzo(b)fluor- } \\
\text { anthene }\end{array}$ & 0.70 & ND & $0.47-102.7$ & 1.4 & 0.87 \\
\hline $\begin{array}{l}\text { Benzo(g,h,i)- } \\
\text { perylene }\end{array}$ & 44 & 0.37 & $65.4-81.9$ & ND & ND \\
\hline $\begin{array}{l}\text { Benzo(k)fluor- } \\
\text { anthene }\end{array}$ & 1.5 & 0.53 & $11.8-14$ & 1.1 & ND \\
\hline $\begin{array}{l}\text { 2-Chloro- } \\
\text { naphthalene }\end{array}$ & 6,400 & ND & ND & ND & ND \\
\hline Chrysene & 22 & ND & $0.45-75$ & $0.41-1.0$ & 0.87 \\
\hline Fluoranthene & 3,200 & 0.68 & $48-211.5$ & $1.1-2.1$ & ND \\
\hline Fluorene & 3,200 & ND & $16.2-34.8$ & ND & ND \\
\hline $\begin{array}{l}\text { Indeno(1,2,3- } \\
\text { c,d)pyrene }\end{array}$ & 0.41 & ND & $51.3-52.8$ & ND & ND \\
\hline $\begin{array}{l}\text { Methylnaphtha- } \\
\text { lene }\end{array}$ & 4,000 & ND & $8.1-11.3$ & ND & ND \\
\hline Naphthalene & 3,200 & ND & $2.9-72.2$ & ND & ND \\
\hline Phenanthrene & $\cdots$ & 0.42 & $0.42-259.6$ & $1.0-1.3$ & ND \\
\hline Pyrene & 2,400 & 0.54 & $0.56-167.9$ & $0.94-1.3$ & 0.43 \\
\hline
\end{tabular}

"ND=not detected 
Table VI. Total PAH concentrations found in burn area soil samples.

\begin{tabular}{|l|l|l|l|}
\hline \multicolumn{1}{|c|}{$\begin{array}{c}\text { Sample } \\
\text { Description }\end{array}$} & \multicolumn{1}{|c|}{$\begin{array}{c}\text { Los } \\
\text { Alamos } \\
\text { Locations }\end{array}$} & \multicolumn{1}{|c|}{$\begin{array}{c}\text { IFT Concentrations } \\
\text { (ppm) }\end{array}$} & \multicolumn{1}{|c|}{$\begin{array}{c}\text { Commercial } \\
\text { Laboratory } \\
\text { Concentration (ppm) }\end{array}$} \\
\hline Standard 1 & ----- & $67(134$ expected) & ND $^{\text {a }}$ \\
\hline Burned Excelsior & TA-16-399 & 6.0 & ND \\
\hline Ash Storage Barrel & TA-16 & 12.6 & ND \\
\hline $\begin{array}{l}\text { Ash-Burn Tray } \\
\text { (PBX 9502) }\end{array}$ & TA-16-399 & $<1 \mathrm{ppm}$ & ND \\
\hline $\begin{array}{l}\text { Ash-Burn Tray } \\
\text { (Inert) }\end{array}$ & TA-16-399 & $<1 \mathrm{ppm}$ & ND \\
\hline Standard 2 & & $75(120$ expected) & ND \\
\hline $\begin{array}{l}\text { Ash-Burn Barrel } \\
\text { (detonators) }\end{array}$ & TA-40 & $(2.4)$ & 10.2 \\
\hline $\begin{array}{l}\text { Ash-Burn Barrel } \\
\text { (Q-Site) }\end{array}$ & TA-14 & $(2.4)$ & ND \\
\hline Tar Rock & Local Road & $<1 \mathrm{ppm}$ & ND \\
\hline
\end{tabular}

${ }^{2} \mathrm{ND}=$ not detected

Table VII. Concentration in ppm of total PAHs in crude oil reference sample.

\begin{tabular}{|c|c|}
\hline Company & Total PAH (ppm) \\
\hline Strata Production & 710 \\
\hline LANL & $635^{\mathrm{a}}$ \\
\hline IFT & 23 \\
\hline Commercial Laboratory & 122 \\
\hline
\end{tabular}

a naphthalene (250 ppm),

2-methylnaphthalene ( $300 \mathrm{ppm})$,

fluorene (24 ppm), and

anthracene (61) 